\title{
A Bibliometric Analysis and Visualisation of Research Trends in Allergy of knee Implants
}

\author{
Jasgurpreet Singh Chauhan ${ }^{\text {a }}$ \\ Department of Mechanical Engineering, Chandigarh University, \\ Gharuan,Punjab,India. 140413
}

Article History: Received: 11 January 2021; Accepted: 27 February 2021; Published online: 5 April 2021

\begin{abstract}
Several metals are used for Knee implants. The allergy of metals used for knee implants is an important issue to be addressed. The bibliometric analysis had been conducted to understand the active authors, organizations, journals, and countries involved in the research domain of "Allergy of knee implants". All published articles related to "Allergy of knee implants" from "Scopus", were analyzed using the VOS viewer to develop analysis tables and visualization maps. This article had set the objective to consolidate the scientific literature regarding "Allergy of knee implants" and also to find out the trends related to the same. The most active journals in this research domain were the Contact Dermatitis. The most active countries were Germany and Italy. The leading organization engaged in research regarding knee implants was the Ludwig Maximilian University of Germany. The most active authors were Thomas P.; Arkansan J.N, and Drancourt M.
\end{abstract}

Keywords: knee-implants, Metal allergy, Material engineering, Bibliometric analysis, VOS viewer,

\section{Introduction}

An engineered medical device to replace a missing or damaged biological structure is known as an implant. Human knee joints are facing numerous problems including wear, damage, and accidents. Total knee replacement surgery can improve quality of life in cases where repair of the knee is impossible. A knee implant is placed in the knee joint in cases of total knee replacement. knee implants are often used subjected to wear and corrosion and ultimately lead to poor performance, pain, and wastage of money. Material engineering and surface engineering can play a significant role in the development of new types of knee implants; and in enhancing the performance of knee implants[1]-[4].

One of the main challenges associated with knee implants is the wear and friction of knee implants. Hypersensitivity to Nickel is a serious issue associated with Nickel based knee implants, which can even lead to failure of Nickel knee implants [5]-[11]. Similarly, high metal concentration on the body had also been reported as an adverse effect of Nickel-based knee implants [12][13]; wear debris from knee replacements may cause chromosomal damages in human cells [14]. Other metals can be good alternatives for knee implants, where patients having hypersensitivity to Nickel. allergic skin disease is another issue associated with patients who underwent chromium-based implants. This happens due to corrosion and the release of wear debris and high levels of metal ions in the blood [15]. Similarly, dermatitis associated with Chromium following total knee arthroplasty [16] Sensitivity to Chromium and wear may also lead to the loosening of a component of the prosthesis after total joint replacement [17] serious adverse health issues had been reported on chromium implants [18]. In short, the allergy of knee implants is the allergy of metal on which the implant was based.

This bibliometric analysis will be a useful platform for future researchers by realizing the top researchers, organizations, and countries involved in research regarding allergy of knee implants. This article is arranged into four sections. The first section is the introduction, followed by the discussion of the methodology by which the research was conducted. The third section deals with results and discussion. The fourth section deals with the conclusion. The following research objectives and research questions were framed for conducting bibliometric analysis systematically.

\subsection{Research Objectives}

a) To consolidate the literature regarding allergy of knee implants

b) To find out the trends related to research in allergy of knee implants

\subsection{Research Questions}

a) Who are the active researchers working on the allergy of knee implants?

b) Which are the main organizations and countries working on the allergy of knee implants?

c) Which are the main journals related to the allergy of knee implants?

\section{Research Methodology}

Scopus files had been used for this article. For the article selection, the Boolean used was TITLE (knee implant) on 25/02/2021. All the tables in this paper were created by using Microsoft Excel and VOS Viewer. Grammarly 
was used for spelling and grammar checks. Mendeley was used for article review and citation. This paper had been inspired by bibliometric analysis in its presentation style, analysis, and methodology from the works [19]-[25].

\section{Results and discussion}

\subsection{Results}

This first round of search produced an outcome of 130 documents, in five languages, out of which 103 documents were in English. The classification of document categories is shown in Figure 1. For improving the quality of the analysis, we had selected only the peer-reviewed articles and all other documents had not been considered. Thus after using filters "Article" and "English" the second round search produced an outcome of 72 English articles (both open access and others). This paper had used all English articles to conduct bibliometric analysis and visualization using VOS Viewer. The English research articles in this domain since 1976 had been shown in Figure 2.

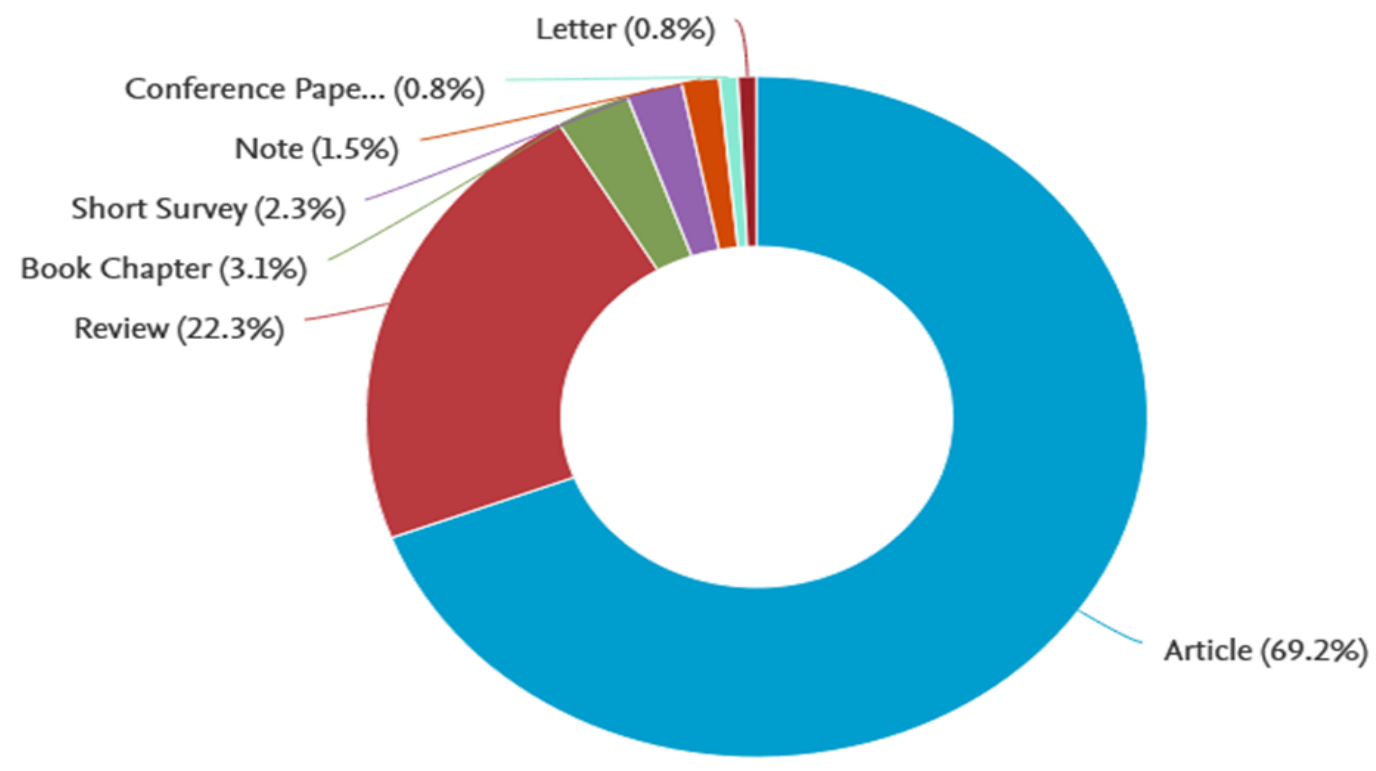

Figure 1: Classification of the documents on "Allergy knee implants", Source: www.scopus.com

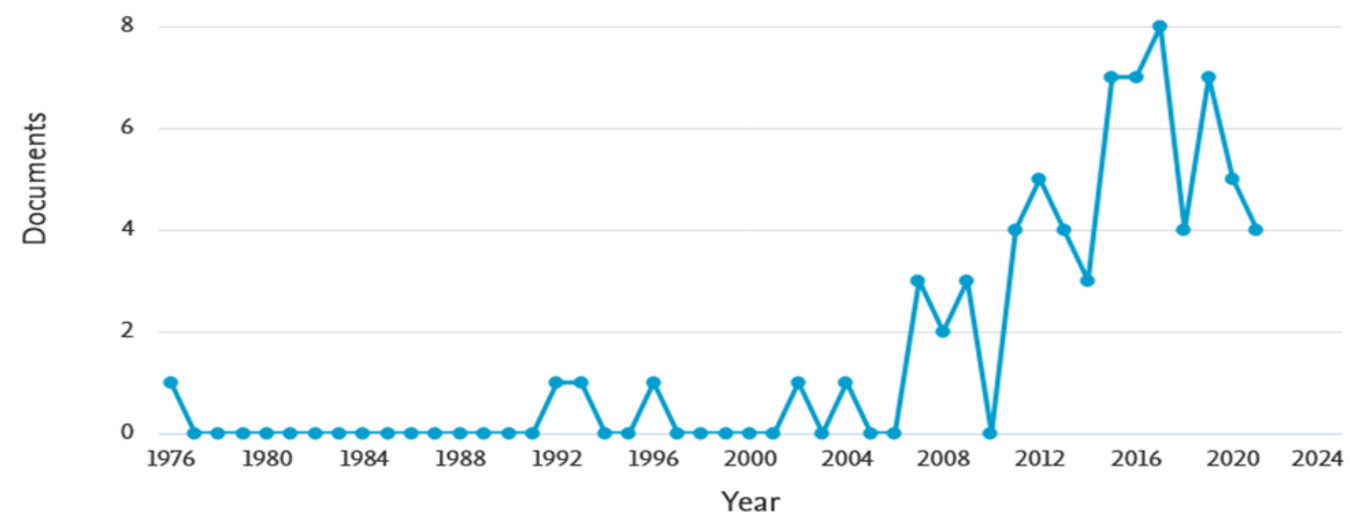

Figure 2: Period wise publication of articles, Source: WWW.scopus.com

Co-authorship analysis of top authors had been shown in figure 3 . For a better presentation of the analysis, the parameters used were the minimum number of documents of an author as two and the minimum number of citations of authors as one. This combination plotted the map of 34 authors, in 9 clusters. The overlay visualization map of co-authorship analysis plotted in Figure 3, points out the major researchers with their strong co-authorship linkages and clusters involved. 


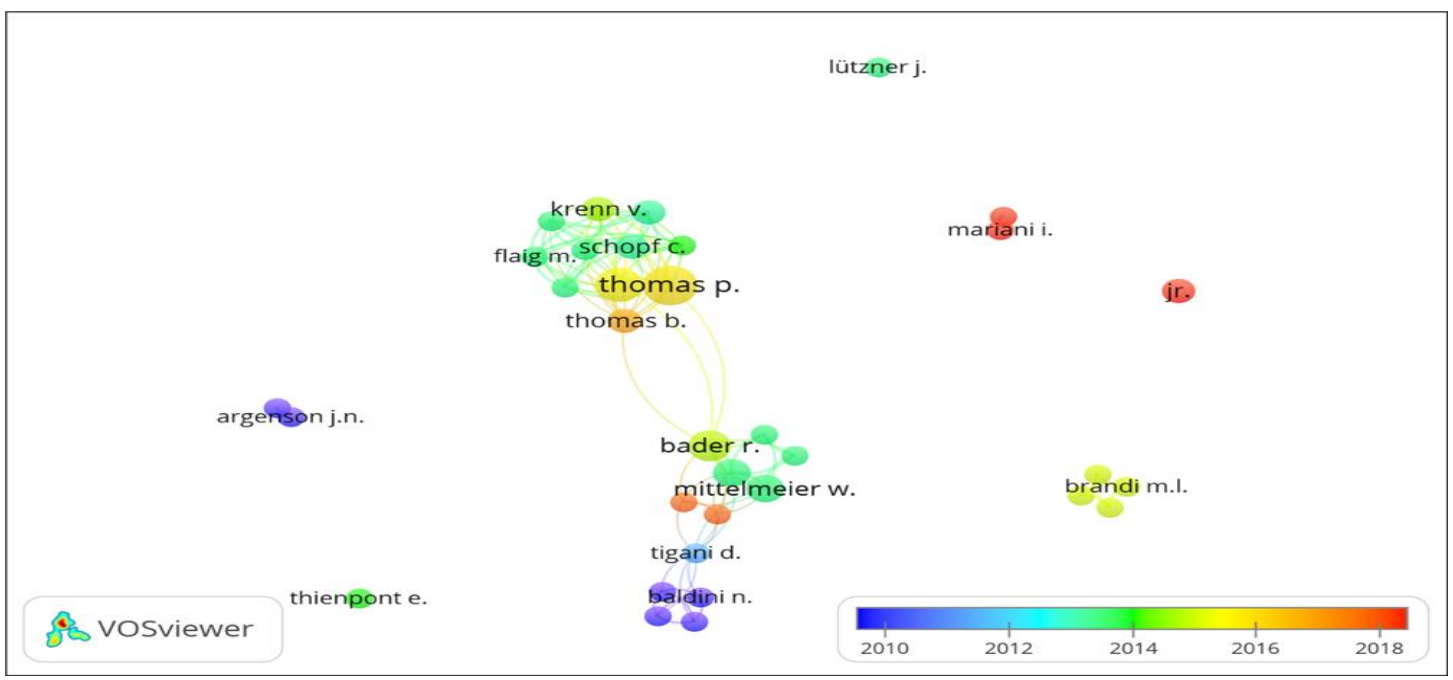

Figure 3: Co-authorship analysis on basis of authors

The citation analysis of top authors had been shown in table 1, along with co-authorship links. For the citation analysis, the parameters used were the minimum number of documents of an author as one and the minimum citations of an author as one.

Table 1: Highlights of most active authors

\begin{tabular}{|c|r|r|r|r|r|}
\hline Description & Authors & Documents & Citations & $\begin{array}{c}\text { Average } \\
\text { citations per } \\
\text { documents }\end{array}$ & $\begin{array}{c}\text { Link } \\
\text { strength }\end{array}$ \\
\hline $\begin{array}{c}\text { Authors with the } \\
\text { highest publication } \\
\text { and co-authorship } \\
\text { links }\end{array}$ & Thomas P. & 8 & & \\
\hline $\begin{array}{c}\text { Authors with the } \\
\text { highest citations }\end{array}$ & Argenson J.N & 2 & 234 & 10.5 & 59 \\
\cline { 2 - 6 } & Drancourt M. & 2 & 234 & 117 & 9 \\
\hline
\end{tabular}

In Co-occurrence analysis, we had used all keyword analyses, by keeping the minimum number of occurrences of a keyword as 20. This combination plotted the map of 27 thresholds, in two clusters. The overlay visualization of co-occurrence analysis of keywords has been shown in Figure 4.

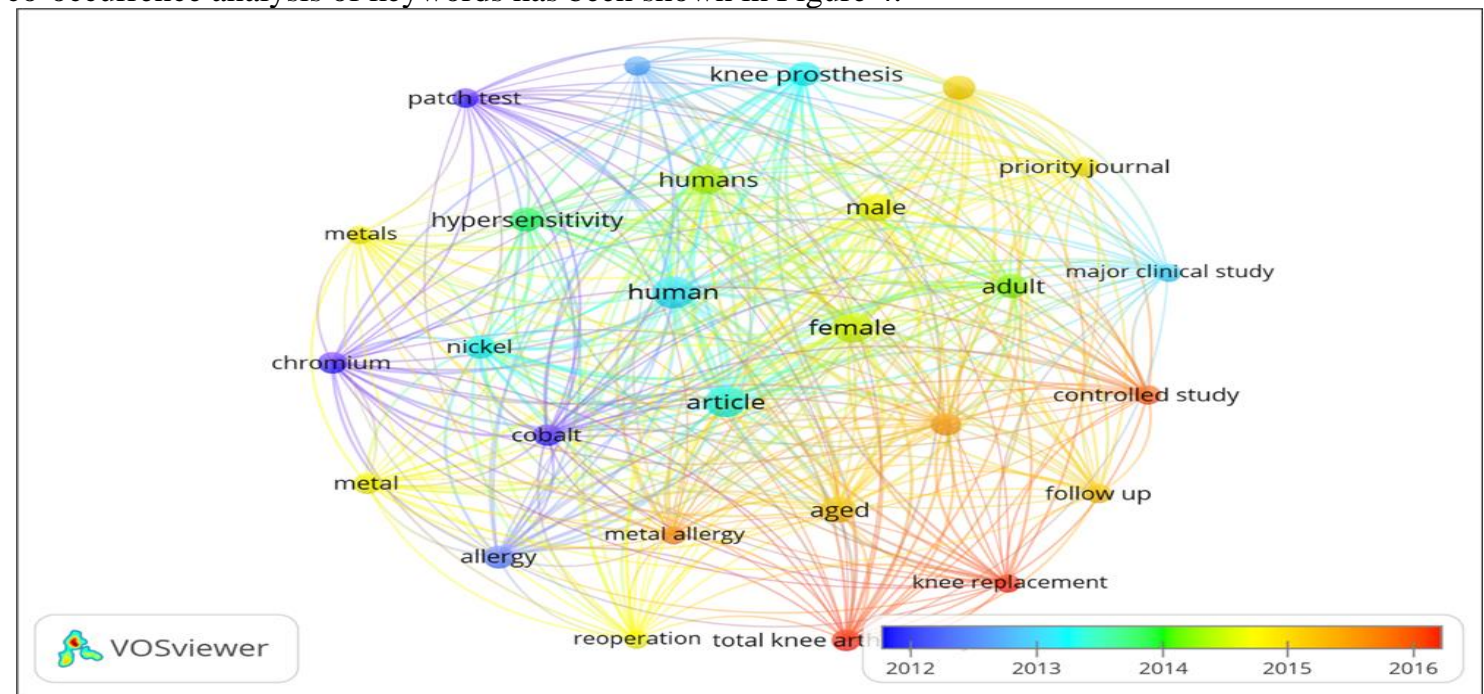

Figure 4: Co-occurrence analysis on basis of all keywords

The leading organizations engaged in research on "Allergy of knee implants" had been found out by the volume of publications and citation analysis, the parameters used are the minimum number of documents of an organization as one and the minimum number of citations of organizations as one. The leading organization in the research regarding "Allergy of knee implants", with the highest number of publications and citations, was the Ludwig Maximilian University of Munich, Germany (Refer to table 2).

Table 2: Highlights of the most active organization 


\begin{tabular}{|c|c|c|c|c|}
\hline Organizations & Country & $\mathrm{s}$ Document & ns & $\begin{array}{l}\text { Average } \\
\text { Citations } \\
\text { per } \\
\text { document }\end{array}$ \\
\hline $\begin{array}{c}\text { Ludwig Maximilian University } \\
\text { of Munich }\end{array}$ & Germany & 8 & 85 & 10.4 \\
\hline
\end{tabular}

Co-authorship analysis of the countries engaged in the research on "Allergy of knee implants" had been shown in Figure 5. The overlay visualization map of co-authorship analysis plotted in Figure 5, points out the main countries with their strong co-authorship linkages and clusters involved.

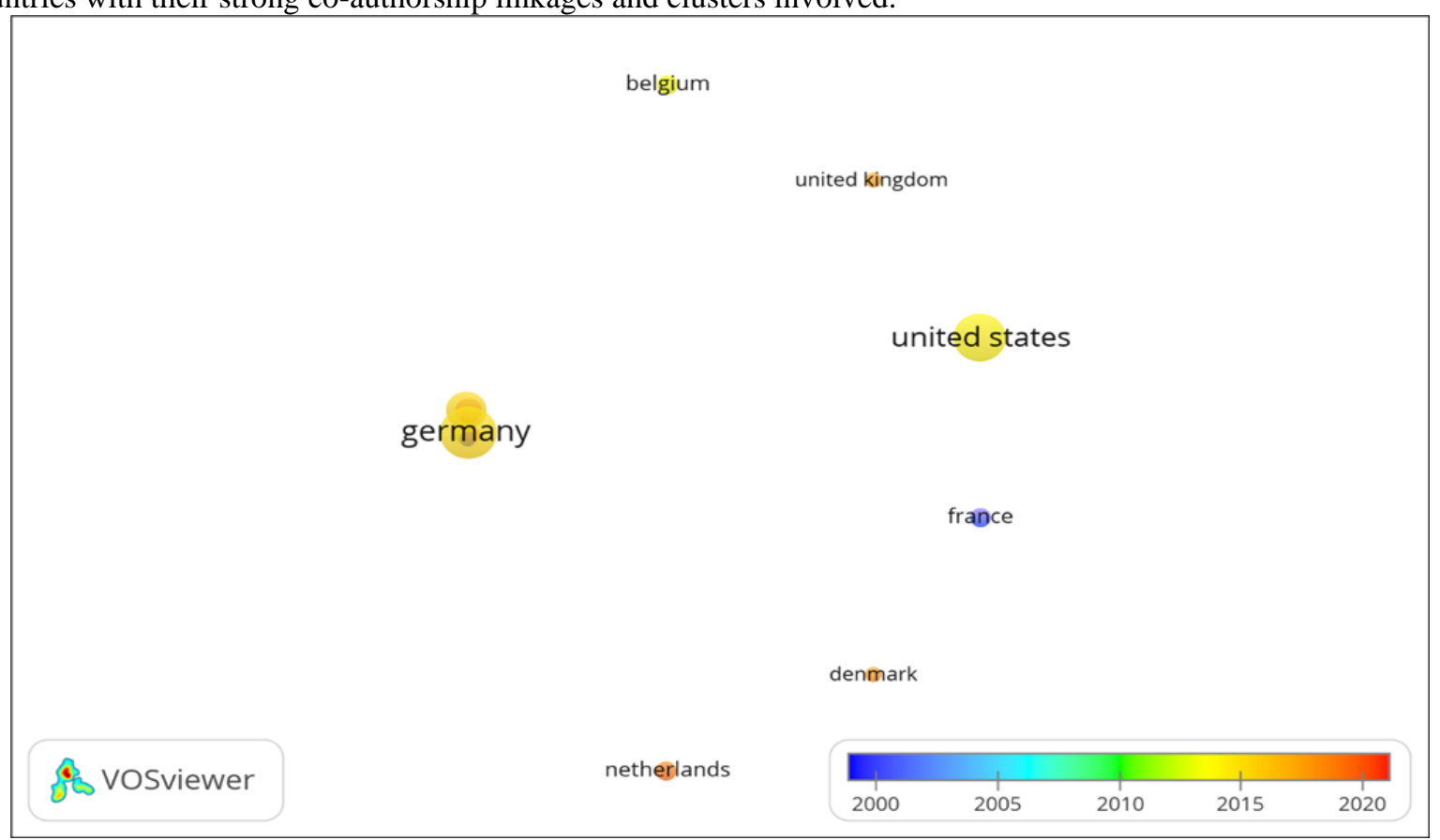

Figure 5: Co-authorship analysis on basis of countries

The citation analysis of top countries had been shown in table 3, along with co-authorship links. For the citation analysis, the parameters used were the minimum number of documents of a country as one and the minimum citations of the country as one.

Table 3: Highlights of Active Countries

\begin{tabular}{|c|c|c|c|c|}
\hline Description & Country & Document & Citation & Link strength \\
\hline \multirow{3}{*}{$\begin{array}{l}\text { Leading countries in } \\
\text { research on allergies of Knee } \\
\text { implants }\end{array}$} & Germany & 22 & 306 & 7 \\
\hline & Italy & 11 & 340 & 5 \\
\hline & $\begin{array}{l}\text { United States of } \\
\text { America }\end{array}$ & 18 & 288 & 0 \\
\hline
\end{tabular}

The most active countries in this research domain were Germany and Italy with the highest number of publications, co-authorship links; and citations respectively.

Link analysis and citation analysis were used to identify the most active journal in this research domain. We have taken the parameters of the minimum number of documents of a journal as one and the minimum number of citations of a journal as one for the link analysis and citation analysis. Highlights of the most active and relevant journals related to "Allergy of knee implants" are shown in table 4. Table 4 shows the journal activity of this research domain through parameters of publication volume, citations, and co-authorship linkages.

Table 4: Analysis of journal activity

\begin{tabular}{|c|c|r|r|r|r|}
\hline Description & Journal details & Documents & Citations & $\begin{array}{c}\text { Average } \\
\text { citations } \\
\text { per } \\
\text { documents }\end{array}$ & Links \\
\hline $\begin{array}{l}\text { Journal with the } \\
\text { highest publications, } \\
\text { co-authorship links, } \\
\text { and citations }\end{array}$ & $\begin{array}{c}\text { Contact } \\
\text { Dermatitis }\end{array}$ & 7 & 256 & & \\
\hline
\end{tabular}


From the above discussion regarding the bibliometric patterns in the research regarding allergy of knee implants, this research had observed a gradual increase in research interest regarding allergy of knee implants from the starting of the millennium and the momentum is going on positively. This points out the relevance and potential of this research domain (Refer to Figure 2). The most active authors in this research domain were Thomas P.; Argenson J.N, and Drancourt M. with the highest publication, co-authorship links; and citations respectively (Refer to table 1). The overlay analysis of top countries researching allergy on knee implants indicates that Germany and Italy were the leading countries relating to the highest number of publications citations, co-authorship links (Refer to figure 5). The top journals of this research domain were identified as the Contact Dermatitis with the highest number of publications, citations, and links. From these wide sources of information, researchers can focus on top journals where they can identify the most relevant and highly cited articles regarding allergy of knee implants.

\section{Conclusion}

The knee implant was an interesting research domain and the most active journals related to this research domain were the Contact Dermatitis. The most active countries were Germany and Italy. The leading organization engaged in research regarding knee implants was the Ludwig Maximilian University of Germany. The most active authors who had made valuable contributions related to dental implants were Thomas P.; Argenson J.N, and Drancourt M.

\section{References}

A. A. Kolkailah et al., "Bibliometric Analysis of the Top 100 Most Cited Articles in the First 50 Years of Heart Transplantation,” Am. J. Cardiol., vol. 123, no. 1, pp. 175-186, 2019.

A. Apostolopoulos, T. Balfousias, S. Khan, B. Srikanth, and G. Tselentakis, "Failure of a medial unicompartmental knee replacement due to metal allergy," J. Long. Term. Eff. Med. Implants, vol. 28, no. 4, pp. 319-325, 2018.

A. Cracchiolo III. and P. Revell, "Metal concentration in synovial fluids of patients with prosthetic knee arthroplasty," Clin. Orthop. Relat. Res., vol. No. 170, pp. 169-174, 1982.

A. D. Bloemke and H. D. Clarke, "Prevalence of self-reported metal allergy in patients undergoing primary total knee arthroplasty,” J. Knee Surg., vol. 28, no. 3, pp. 243-246, 2015.

A. T. Abbas et al., "Sustainability assessment associated with surface roughness and power consumption characteristics in nanofluid MQL-assisted turning of AISI 1045 steel," Int. J. Adv. Manuf. Technol., vol. 105, no. 1-4, pp. 1311-1327, Nov. 2019.

B. Daley, A. T. Doherty, B. Fairman, and C. P. Case, "Wear debris from hip or knee replacements causes chromosomal damage in human cells in tissue culture," J. Bone Jt. Surg. - Ser. B, vol. 86, no. 4, pp. 598606, 2004.

C. X. Tran et al., "The current research landscape of the application of artificial intelligence in managing cerebrovascular and heart diseases: A bibliometric and content analysis," Int. J. Environ. Res. Public Health, vol. 16, no. 15, 2019.

D. D. Ramteke, A. Balakrishna, V. Kumar, and H. C. Swart, "Luminescence dynamics and investigation of Judd-Ofelt intensity parameters of Sm3+ ion containing glasses," Opt. Mater. (Amst)., vol. 64, pp. 171$178,2017$.

1. G. C. Brown, M. D. Lockshin, E. A. Salvati, and P. G. Bullough, "Sensitivity to metal as a possible cause of sterile loosening after cobalt chromium total hip replacement arthroplasty,” J. Bone Jt. Surg. - Ser. A, vol. 59, no. 2, pp. 164-168, 1977.

I. Shahid et al., "Characteristics of highly cited articles in heart failure: A bibliometric analysis,” Future Cardiol., vol. 16, no. 3, pp. 189-197, 2020.

2. J. Beecker, J. Gordon, and M. Pratt, “An interesting case of joint prosthesis allergy,” Dermatitis, vol. 20, no. 2, pp. E4-E9, 2009.

3. J. Liao et al., "The most cited articles in coronary heart disease: A bibliometric analysis between 1970 and 2015,” Int. J. Cardiol., vol. 222, pp. 1049-1052, 2016.

4. J. R. Campbell and M. P. Estey, "Metal release from hip prostheses: Cobalt and chromium toxicity and the role of the clinical laboratory," Clin. Chem. Lab. Med., vol. 51, no. 1, pp. 213-220, 2013.

5. L. Rodríguez-Padial et al., "Trends and Bibliometric Impact of Research Grants of the Spanish Society of Cardiology/Spanish Heart Foundation (2007-2012) [Evolución e impacto bibliométrico de las becas de la Sociedad Española de Cardiología/Fundación Española del Corazón en el periodo 2007-2012]," Rev. Esp. Cardiol., vol. 72, no. 12, pp. 1012-1019, 2019.

6. M. Dezulovic, U. Baur, R. Stangl, W. Baur, and E. Lenz, "Nickel allergy and painful unicondylar knee arthroplasty [Nickelallergie und schmerzhafte monokondyläre Kniegelenksschlittenprothese], ' Z. Orthop. Unfall., vol. 150, no. 3, pp. 269-271, 2012.

7. M. M. Desai, K. A. Shah, A. Mohapatra, and D. C. Patel, "Prevalence of metal hypersensitivity in total knee replacement," J. Orthop., vol. 16, no. 6, pp. 468-472, 2019.

8. M. Wolff, C. Haasper, A. Zahar, C. Gauck, T. Gehrke, and M. Citak, "Severe metallosis and elevated chromium in serum following implantation of the joint unloading implant system," Arch. Orthop. Trauma Surg., vol. 137, no. 12, pp. 1751-1754, 2017. 
9. N. Aggarwal, K. Kaur, A. Vasishth, and N. K. Verma, "Structural, optical and magnetic properties of Gadolinium-doped ZnO nanoparticles,” J. Mater. Sci. Mater. Electron., vol. 27, no. 12, pp. 13006-13011, 2016.

10. N. Bizzotto et al., "Chromium-induced diffuse dermatitis with lymph node involvement resulting from Langerhans cell histiocytosis after metal-on-metal hip resurfacing,” Br. J. Dermatol., vol. 172, no. 6, pp. 1633-1636, 2015.

11. P. Bergschmidt, R. Bader, and W. Mittelmeier, "Metal hypersensitivity in total knee arthroplasty: Revision surgery using a ceramic femoral component - A case report," Knee, vol. 19, no. 2, pp. 144-147, 2012.

12. S. Akil, J. M. Newman, N. V Shah, N. Ahmed, A. J. Deshmukh, and A. V Maheshwari, "Metal hypersensitivity in total hip and knee arthroplasty: Current concepts," J. Clin. Orthop. Trauma, vol. 9, no. 1, pp. 3-6, 2018.

13. S. Ullah, S. U. Jan, H. U. Rehman, N. I. Butt, M. A. Rauf, and S. Shah, "Publication trends of Pakistan Heart Journal: A bibliometric study,” Libr. Philos. Pract., vol. 2019, 2019.

14. T. Farhat et al., "Research in congenital heart disease: A comparative bibliometric analysis between developing and developed countries," Pediatr. Cardiol., vol. 34, no. 2, pp. 375-382, 2013.

15. U. Singh and R. Salgotra, "Synthesis of linear antenna array using flower pollination algorithm," NEURAL Comput. Appl., vol. 29, no. 2, pp. 435-445, Jan. 2018.

16. X. Gao, R.-X. He, S.-G. Yan, and L.-D. Wu, "Dermatitis Associated With Chromium Following Total Knee Arthroplasty,” J. Arthroplasty, vol. 26, no. 4, p. 665.e13-665.e16, 2011. 